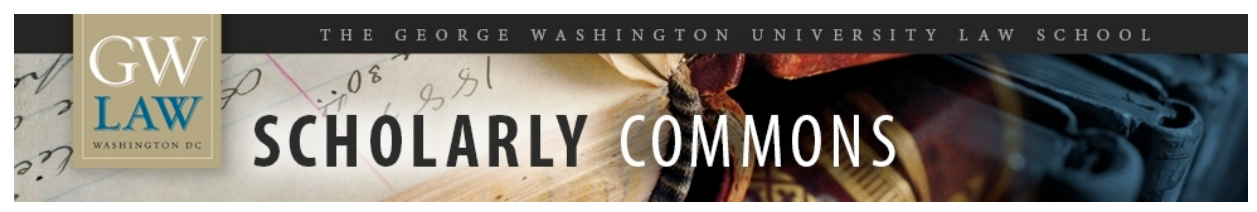

\title{
The ILO Convention on Freedom of Association and its Future in the United States
}

Steve Charnovitz

George Washington University Law School, scharnovitz@law.gwu.edu

Follow this and additional works at: https://scholarship.law.gwu.edu/faculty_publications

Part of the Law Commons

\section{Recommended Citation}

Steve Charnovitz, The ILO Convention on Freedom of Association and its Future in the United States, 102 Am. J. Int'I L. 90 (2008).

This Article is brought to you for free and open access by the Faculty Scholarship at Scholarly Commons. It has been accepted for inclusion in GW Law Faculty Publications \& Other Works by an authorized administrator of Scholarly Commons. For more information, please contact spagel@law.gwu.edu. 
The ILO Convention on Freedom of Association and Its Future in the United States

$$
\text { By Steve Charnovitz* }
$$

Freedom of association is a bedrock principle of international labor law. In 1919 the Allied powers expressed "recognition of the principle of freedom of association" in part XIII (Labour) of the Treaty of Versailles, which became the Constitution of the International Labour Organization (ILO). ${ }^{1}$ Nearly three decades later, in 1948, the ILO adopted the landmark Convention Concerning Freedom of Association and Protection of the Right to Organize (No. 87). ${ }^{2}$ Article 2 of C. 87 declares: "Workers and employers, without distinction whatsoever, shall have the right to establish and, subject only to the

* Published in Vol. 102 of the American Journal of International Law, 2008.

The author thanks Charles Craver, Janelle Diller, Ronnie Goldberg, Abraham Katz, Francis Maupain, and Anne Trebilcock for their helpful comments.

1 Treaty of Peace with Germany (Treaty of Versailles), pt. XIII, pmbl., June 28, 1919, 2 Bevans 43; see also id., Art. 427 (General Principles) (including "[t]he right of association for all lawful purposes by the employed as well as by the employers”). The current ILO Constitution includes the original preambular provision but omits the provision in Article 427, which was replaced with revised general principles in the ILO Declaration of Philadelphia of 1944. That declaration reaffirms that "freedom of expression and of association are essential to sustained progress.” ILO Const., annex, para. 1(b), available at <http://www.ilo.org/ilolex/english/constq.htm>. In 1948 the U.S. Congress authorized the United States to accept the revised ILO Constitution, which includes the Declaration of Philadelphia. Act of June 30, 1948, Pub. L. No. 80-843, 62 Stat. 1151.

${ }^{2}$ Convention Concerning Freedom of Association and Protection of the Right to Organise (No. 87), July 9, 1948, 68 UNTS 17 [hereinafter C. 87]. Several months later, in December 1948, the UN General Assembly adopted the Universal Declaration of Human Rights, which contains provisions regarding freedom of association and the right to join (or not join) labor unions. Universal Declaration of Human Rights, GA Res. 217A (III), Arts. 20(1), 23(4), UN Doc. A/810, at 71 (1948). For background on C. 87, see Harold Dunning, The Origins of Convention No. 87 on Freedom of Association and the Right to Organize, 137 INT'L LAB. REV. 149 (1998). 
rules of the organisation concerned, to join organisations of their own choosing without previous authorisation.”3

Although the U.S. government voted in the ILO for the adoption of C. 87, the United States has not ratified it. ${ }^{4}$ President Harry S. Truman recognized the importance of C. 87 by transmitting it to the U.S. Senate for advice and consent in $1949 .{ }^{5}$ The transmittal included a letter from Secretary of State Dean Acheson expressing the coordinated views of interested agencies and departments of the U.S. government that "the subject matter of the convention is appropriate under our constitutional system for Federal action" under Article 19(7)(a) ${ }^{6}$ of the ILO Constitution. ${ }^{7}$ In addition, Acheson's letter expressed the administration’s view that “no new Federal legislation or revision of existing Federal law is necessary to effect compliance by the United States with the terms

${ }^{3}$ C. 87, supra note 2, Art. 2.

${ }^{4}$ The Convention was adopted by 127-0 (with 11 abstentions) at the ILO Conference held in San Francisco. The U.S. government, worker, and employer delegates voted for the Convention. InT’L Lab. Conf., Record of ProceEdings, 31st Sess. 268 (1948).

${ }^{5}$ Message from the President of the United States Transmitting the Convention (No. 87) Concerning Freedom of Association and Protection of the Right to Organize, S. ExEC. Doc. No. 81-S (1949).

${ }^{6}$ Letter from the Secretary of State to the President (Aug. 26, 1949), reprinted in id. at 2, 2.

7 Article 19(7)(a) states:

In the case of a federal State, the following provisions shall apply:

(a) in respect of Conventions and Recommendations which the federal government regards as appropriate under its constitutional system for federal action, the obligations of the federal State shall be the same as those of Members which are not federal States.

ILO Const., supra note 1, Art. 19(7)(a). Article 19(7) contains sophisticated provisions governing the obligations of federal states. 
of the convention.”8 This position was based on the assumption that freedom of association is protected by the U.S. Constitution and that any inconsistent federal or state law would be unconstitutional. ${ }^{9}$

Nearly sixty years later, C. 87 continues to lie on the shelf in the Senate. It is the longest-pending treaty on the calendar of the Senate Committee on Foreign Relations. ${ }^{10}$ Despite its substantive and symbolic importance, the Convention on Freedom of Association has become the untouchable treaty in American politics.

\section{THE ILO AND FREEDOM OF ASSOCIATION}

Within the ILO, C. 87 has grown in importance and gained wide acceptance. As of December 2007, 148 states had ratified C. 87, equal to 82 percent of the ILO’s membership. ${ }^{11}$ Of those ratifications, 28 came about within the past decade. In one somewhat ironic episode, Indonesia ratified C. 87 in 1998 after being urged to do so by the U.S. government and the International Monetary Fund. ${ }^{12}$

${ }^{8}$ Letter from the Secretary of State to the President, supra note 6, at 2.

${ }^{9}$ See U.S. Dep't of Labor, Briefing Paper on ILO Convention 87 Concerning Freedom of Association (Oct. 1980), reprinted in The United States and the International Labor Organization: Hearing Before the S. Comm. on Labor and Human Resources, 99th Cong. 49, 52 (1985).

${ }^{10}$ U.S. Dep't of State, Office of the Legal Adviser, Treaties Pending in the Senate (Updated as of July 13, 2007), available at <http://www.state.gov/s///treaty/pending>. The next two oldest treaties are ILO conventions transmitted in 1962 and 1966.

${ }^{11}$ The United States is not alone in failing to join C. 87. Fully 33 ILO member countries have not ratified it, including, for example, Afghanistan, Bahrain, Brazil, China, India, Iran, Iraq, Malaysia, New Zealand, Saudi Arabia, Singapore, South Korea, and Thailand.

${ }^{12}$ Prepared Statement of Timothy Geithner, Treasury Under Secretary, Before the Subcomm. on Asia and the Pacific of the H. Comm. on Int'l Relations (Feb. 16, 2000), 
The Convention on Freedom of Association enjoys a special status within the ILO. In 1951 the ILO Governing Body established the tripartite ${ }^{13}$ Committee on Freedom of Association (CFA), mandated to examine complaints about violations of the associational rights of a labor union. A complaint may be filed against a government by another government or by qualified organizations of workers or employers. Besides C. 87, the CFA also supervises implementation of the core ILO Convention Concerning the Right to Organise and Bargain Collectively (No. 98). ${ }^{14}$ The CFA has long been lauded for its contribution to human and labor union rights, and benefited for over three decades from the leadership of Judge Roberto Ago. ${ }^{15}$ The committee has examined over 2600 cases.

The CFA may hear a complaint about a government's violation of freedom of association regardless of whether the accused government is party to C. 87. Indeed, the CFA has considered 49 cases against the United States. The inclusive terms of reference

available in LEXIS, U.S. Congress Library, Fed. News Serv. File; see also 19 U.S.C. $\S 262 p-4 p$ (2000) (calling on the secretary of the treasury to urge international financial institutions to encourage borrowing countries to use relevant ILO conventions in taking action to guarantee internationally recognized worker rights).

13 The ILO is organized on the tripartite principle of representation of each member state by two government delegates, one worker delegate, and one employer delegate.

${ }^{14}$ Convention Concerning the Application of the Principles of the Right to Organise and Bargain Collectively (No. 98), July 1, 1949, 96 UNTS 257. In a nutshell, C. 98 aims at protecting workers vis-à-vis employers, while C. 87 aims at protecting workers vis-à-vis governments. HÉCTOR BARTOLOMEI DE LA CRUZ, GERALDO VON POTOBSKY, \& LEE SWEPSTON, THE INTERNATIONAL LABOR ORGANIZATION: THE INTERNATIONAL STANDARDS System AND BASIC HUMAN RighTS 171 (1996). The ILO conventions referred to in this Editorial are available online at $<$ http://www.ilo.org/global/What_we_do/InternationalLabourStandards/langen/index.htm>.

${ }^{15}$ Nicolas Valticos, Roberto Ago (1907-1995), 89 AJIL 581, 583 (1995). 
for the CFA were agreed to because of the fundamental nature of the right of association. ${ }^{16}$ Thus, the CFA has held: "When a State decides to become a Member of the [International Labour] Organization, it accepts the fundamental principles embodied in the Constitution and the Declaration of Philadelphia, including the principles of freedom of association." ${ }^{\text {17 }}$ ILO member states are expected to reply to the CFA and to respond to its recommendations. Nevertheless, if a state has not ratified C. 87, CFA review of that state's practices cannot itself lead to an international legal obligation to comply with the Convention.

If the CFA finds a violation of commitments on freedom of association by a state that has ratified C. 87, the CFA may refer the case for follow-up to the ILO's Committee of Experts on the Application of Conventions and Recommendations. ${ }^{18}$ This process puts normative pressure on governments but does not generate a new legal obligation to comply. Under the ILO Constitution, the obligation to comply with a ratified convention already exists. ${ }^{19}$

\footnotetext{
${ }^{16}$ Victor-Yves GHebali, The International Labour Organisation: A CASE StUdy ON THE EVOLUTION OF U.N. SPECIALISED AgENCIES 77-80 (1989).

${ }^{17}$ ILO, Freedom of Association: Digest of DeCisions AND PRinciples of THE FREEDOM OF ASSOCIATION COMMITTEE OF THE GOVERNING BODY OF THE ILO, para. 15 (5th rev. ed. 2006), available at <http://www.ilo.org/ilolex/english/23e2006.pdf $>$. For the Declaration of Philadelphia, see note 1 supra.

${ }^{18}$ The Committee of Experts is an independent committee (composed of twenty eminent jurists) that examines reports by governments on the application of ratified conventions, receives comments from worker and employer nongovernmental organizations, and asks governments to take needed action to apply ratified conventions fully. For example, in the late 1970s, the committee reviewed allegations regarding violations of C. 87 by the Soviet Union. Theodor Meron, Violations of ILO Conventions by the USSR and Czechoslovakia, 74 AJIL 206 (1980).

${ }^{19}$ ILO Const., supra note 1, Art. 19(5)(d).
} 
Legal obligations may emerge from the complaint process provided for in Article 26 of the ILO Constitution. If a party to a convention is alleged to be out of compliance, a complaint may be lodged by a nongovernmental delegate or by a state that is a party to that convention. When this procedure is invoked, the ILO Governing Body may refer the complaint to a commission of inquiry that will investigate, issue findings, and make recommendations. Since 1919, eleven commissions of inquiry have been established. The findings and recommendations of the commission can become binding if the defaulting government accepts the findings, or as a result of an adjudication by the International Court of Justice if the matter is referred to it. ${ }^{20}$

The fundamental status of the freedom of association was reinforced in 1998 when the ILO’s annual International Labor Conference adopted the Declaration on

${ }^{20}$ Id., Arts. 29(2), 31-34; Francis Maupain, Is the ILO Effective in Upholding Workers' Rights?: Reflections on the Myanmar Experience, in LABOUR RightS As HUMAN RIGHTS 85, 99 \& n.45 (Philip Alston ed., 2005); Francis Maupain, The Settlement of Disputes Within the International Labour Office, 2 J. INT’L ECON. L. 273, 278-79 (1999); Budislav Vukas, Some Remarks Concerning the Commissions of Inquiry Established Under the Constitution of the International Labour Organization, in LES NORMES INTERNATIONALES DU TRAVAIL: UN PATRIMOINE POUR L'AVENIR. MÉLANGES EN L'HONNEUR DE NICOLAS VALticos 75, 78-79 (Jean-Claude Javillier \& Bernard Gernigon eds., 2004). In principle, either the complainant government or the respondent government could have recourse to the ICJ to contest the findings and recommendations of the commission of inquiry. The ICJ would seem to have jurisdiction because it is specifically provided for in the treaty establishing the ILO Constitution. How the ICJ might assess its competence remains to be seen, as the judicial provisions in the ILO Constitution (which hark back to 1919) have not been used. ILO Const., supra, Art. 29(2); ICJ Statute, Art. 36(1).

One jurisdictional issue is that states do not call an ILO commission of inquiry into being. Instead, the ILO Governing Body can set up a commission on its own or following a complaint by a state. ILO Const., supra, Art. 26(1), (4). Thus, commentators have raised the question whether the intervening role of the Governing Body in setting up the commission could deprive the ICJ of jurisdiction because no formal dispute between two states would exist. See, e.g., Anne-Marie La Rosa, Links Between the ILO and the ICJ: A Less Than Perfect Match, in INTERNATIONAL ORGANIZATIONS AND InTERnational Dispute SetTlement: Trends and Prospects 119, 126-29 (Laurence Boisson de Chazournes, Cesare P. R. Romano, \& Ruth Mackenzie eds., 2002). 
Fundamental Principles and Rights at Work. ${ }^{21}$ In this nonlegally binding declaration, the conference

[d]eclares that all Members, even if they have not ratified the Conventions in question, have an obligation arising from the very fact of membership in the Organization to respect, to promote and to realize, in good faith and in accordance with the Constitution [of the ILO], the principles concerning the fundamental rights which are the subject of those Conventions, namely:

(a) freedom of association and the effective recognition of the right to collective bargaining;

(b) the elimination of all forms of forced or compulsory labour;

(c) the effective abolition of child labour; and

(d) the elimination of discrimination in respect of employment and occupation. $^{22}$

The declaration was carefully drafted to make clear that, under its terms, ILO member states are not obliging themselves to adhere to the ILO conventions covering the fundamental labor principles. Moreover, the declaration was not designed to be enforced through ILO supervisory mechanisms and lacks its own complaint mechanism.

${ }^{21}$ The ILO declaration is examined in Brian Langille, The ILO and the New Economy: Recent Developments, 15 InT’L J. COMP. LAB. L. \& InDUS. REL. 229 (1999); Anne Trebilcock, The ILO Declaration on Fundamental Principles and Rights at Work: A New Tool, in THE ILO AND THE SOCIAL CHALlEngES OF THE 21ST CENTURY: THE GENEVA LECTURES 105 (Roger Blanpain \& Christian Engels eds., 2001).

${ }^{22}$ ILO Declaration on Fundamental Principles and Rights at Work, para. 2, June 18, 1998, available at <http://www.ilo.org/dyn/declaris/DeclarationWeb.IndexPage>. 
Nevertheless, the declaration can influence states because it both concretizes the concept of "fundamental principles and rights at work" and recommits member states to the proposition that ILO membership implies an obligation to respect certain fundamental principles. ${ }^{23}$

The ILO declaration is supported by a "follow-up" procedure asking governments that have not ratified one or more of the fundamental conventions to report annually on the status of the relevant rights and principles within their borders, noting impediments to ratification and areas where technical assistance may be required. ${ }^{24}$ The annual reports by the U.S. government point out ways that the U.S. Constitution and laws protect freedom of association. But the U.S. reports have not discussed impediments to ratification of C. 87.

In abstaining from becoming a party to C. 87 , the United States has disadvantaged itself in several ways. The most important may be the reputational cost within the ILO of not being a party to this core convention. ${ }^{25}$ Of the eight labor rights conventions

${ }^{23}$ The key political momentum for the declaration came from U.S. employers. The declaration received considerable praise when adopted, but recently has come under criticism, most notably by Philip Alston. Philip Alston, 'Core Labour Standards' and the Transformation of the International Labour Rights Regime, 15 EUR. J. INT'L L. 457 (2004). Professor Alston argues that the declaration devalues the legal rights in ILO conventions, that the core standards appear to have been arbitrarily chosen, and that the vagueness of the declaration will make it convenient for use by the United States to justify trade sanctions. For a detailed defense of the declaration by one of its intellectual architects, see Francis Maupain, Revitalization Not Retreat: The Real Potential of the 1998 ILO Declaration for the Universal Protection of Workers' Rights, 16 EUR. J. INT'L L. 439 (2005). Maupain (who served for eleven years as the ILO legal adviser) claims that Alston "gets the story upside down." Id. at 460.

${ }^{24}$ The declaration restates the ILO obligation to provide technical assistance to member governments.

${ }^{25}$ The same conclusion has been expressed in policy commentary for many years. See, e.g., LOUIS B. SOHN ET AL., THE UNITED STATES AND THE INTERNATIONAL LABOR 
identified by the ILO Governing Body as "fundamental,"26 the United States has ratified only two. ${ }^{27}$ The negative fallout from the longtime weak U.S. ratification record has been pointed out in congressional hearings. For example, in 1985 U.S. Secretary of State George P. Shultz testified that U.S. diplomats can

note that the U.S. Constitution, Bill of Rights, and civil rights statutes ensure freedom of association, freedom from forced labor, and equality of opportunity and treatment. These arguments are important, but they do not defuse the charges

ORGanization 22 (26th Report of the Commission to Study the Organization of Peace, 1979) (noting that the United States has the worst ratification record of the eighteen ILO members that are federal states and asserting that "[i]f the United States wishes to be influential within the Organization, it must have a strong record of ratification. Only then would it be assured of being heard when complaining about non-compliance by others.”); The United States and the International Labor Organization: A Report (May 1956), reprinted in 310 ANNALS AM. ACAD. POL. \& Soc. SCI. 182, 187 (1957) [hereinafter Johnson Committee Report] ("We can never effectively participate in the ILO if we continue to become enmeshed in highly formalistic exercises in which we appear to the world to oppose high principles because of an unwarranted concern about the effect of ILO on our own legislative processes.”); William G. Rice, Book Review, 2 Aм. J. Comp. L. 404, 405 (1953) (“[T]he United States remains a very coy ratifier of conventions. . . . The pressure we put on western Europe for greater collective action is somewhat deflated by our example as a member of the I.L.O....").

${ }^{26}$ The eight conventions are the Freedom of Association and Protection of the Right to Organise Convention, 1948 (No. 87); the Right to Organise and Collective Bargaining Convention, 1949 (No. 98); the Forced Labour Convention, 1930 (No. 29); the Abolition of Forced Labour Convention, 1957 (No. 105); the Minimum Age Convention, 1973 (No. 138); the Worst Forms of Child Labour Convention, 1999 (No. 182); the Equal Remuneration Convention, 1951 (No. 100); and the Discrimination (Employment and Occupation) Convention, 1958 (No. 111). ILO, THE INTERNATIONAL LABOUR ORGANIZATION's FUNDAMENTAL CONVENTIONS (2002) (explicating the concept of fundamental conventions).

${ }^{27}$ The two U.S.-ratified conventions are C. 105 and C. 182, both supra note 26. The United States shares with Myanmar the embarrassing record of having ratified only two of the eight fundamental conventions. 
against us brought about by our refusal to consider ratification of all but a few ILO conventions $\ldots{ }^{28}$

Soon afterward, Senator Orrin G. Hatch wrote an op-ed column entitled "Ratify International Labor Conventions"; in it he stated, among many thoughtful points, that “our dismal nonratification record undercuts our credibility at the ILO.”29 In 1989 U.S. Secretary of Labor Elizabeth Dole testified to the Senate Foreign Relations Committee:

Given its tripartite structure and its long-established machinery for supervising the application of ILO standards, it is not surprising [that] the International Labor Organization is the United Nations['] most effective advocate of human rights.

We are all aware, for example, of the ILO's courageous support of Solidarity during the darkest days, and the critical role it has played in Poland's historic journey to democracy.

But our ratification record works against our participation in the ILO's activities precisely in this critical area. And that is a point .... I feel strongly about.

${ }^{28}$ The United States and the International Labor Organization, supra note 9, at 5, 9. Shultz had served as U.S. secretary of labor from 1969 to 1970 and earlier was a professor of industrial relations.

${ }^{29}$ Orrin G. Hatch, Ratify International Labor Conventions, CHRISTIAN SCI. MONITOR, Dec. 10, 1985, at 27. 
Although we are a strong advocate of the ILO’s standardsetting activities and a leading critic of violations of fundamental worker rights, our poor ratification record does raise questions about the sincerity of our efforts.

Our failure to ratify ILO standards subjects us to criticism that we do not practice what we preach. And moreover, it also prohibits us from bringing complaints against other countries for failure to observe standards they have ratified. $^{30}$

\section{LABOR RIGHTS IN U.S. TRADE POLICY}

Failure to ratify fundamental ILO conventions has also undermined the credibility of the United States in its longtime efforts to use trade policy as a means of promoting respect for internationally recognized worker rights. ${ }^{31}$ My experience in 1983-1984 as a U.S. government negotiator on labor rights (in the Caribbean Basin Initiative) revealed the indelicacy of asking other governments to guarantee the right to organize and bargain collectively when the United States itself had not ratified the applicable ILO conventions. $^{32}$

\footnotetext{
${ }^{30}$ S. EXEC. REP. No. 101-16, app. at 12, 14 (1989) (Statement of Elizabeth Dole, secretary of labor). Dole was referring to Article 26 of the ILO Constitution, which permits a member state to file a complaint that another member state is not effectively observing an ILO convention that both states have ratified.

31 Bob Hepple, Labour Laws and Global Trade (2005); Sandra Polaski, Protecting Labor Rights Through Trade Agreements: An Analytical Guide, 10 U.C. DAVIS J. INT’L L. \& POL'Y 13 (2003).

32 Steve Charnovitz, Caribbean Basin Initiative: Setting Labor Standards, MonTHLY LAB. REV., Nov. 1984, at 54.
} 
Although core labor rights have been included as a trade objective in U.S. law for over three decades, none of those statutory provisions refers to C. 87. Curiously, the only specific reference to C. 87 in U.S. law concerns labor rights in Cuba rather than in the United States. That provision states that the United States will observe whether a transitional government in Cuba makes demonstrated progress toward "allowing the establishment of independent trade unions as set forth in conventions 87 and 98 of the International Labor Organization, and allowing the establishment of independent social, economic, and political associations. ${ }^{\text {} 33}$ Meeting the prescribed requirements could effect the lifting of the longtime U.S. trade embargo against Cuba.

By contrast, direct references to ILO conventions can be seen in the trade preference programs of the European Community (EC). In 2005 the Community approved a new program of generalized tariff preferences for developing countries. It offers a special incentive arrangement to a country that "has ratified and effectively implemented" sixteen listed human and labor rights conventions. ${ }^{34}$ One of those conventions is C. 87.

In the most recent decade, even as all U.S. free trade agreements (FTAs) have included rules on labor rights, those rules have been kept detached from multilateral labor conventions. The standoffish attitude in U.S. trade agreements toward ILO conventions contrasts with the unabashed ardor for intellectual property conventions. For intellectual property, U.S. trade agreements expressly require adherence to multilateral treaties on patents, copyrights, and trademarks. For example, the intellectual property chapter of the

3322 U.S.C. §6065(a)(6)(C) (2000). Cuba ratified C. 87 in 1952.

${ }^{34}$ Council Regulation (EC) No. 980/2005 of 27 June 1995 Applying a Scheme of Generalized Tariff Preferences, Art. 9(1) \& Annex III, pt. A, 2005 O.J. (L 169) 1. 
United States-Singapore Free Trade Agreement contains direct references to several international agreements. ${ }^{35}$

Following the U.S. midterm elections in 2006, the Democrats (the new majority party in the U.S. Congress) demanded the insertion of stronger provisions on labor rights into pending bilateral FTAs with Colombia, Panama, Peru, and South Korea. ${ }^{36}$ Specifically, congressional leaders insisted that the FTAs be revised to include commitments by governments regarding fundamental labor rights. The most straightforward approach would have been for both FTA parties to pledge adherence to fundamental ILO conventions. But that approach was blocked for the United States by the absence of U.S. ratification of most of these conventions, including C. $87 .^{37}$

The work-around engineered by congressional leaders and the Bush administration was to link the new FTA commitments not to ILO treaties but, rather, to the 1998 ILO Declaration on Fundamental Principles and Rights at Work. ${ }^{38}$ Once this

${ }^{35}$ United States-Singapore Free Trade Agreement, Art. 16.1, Jan. 15, 2003, available at $<$ http://www.ustr.gov>.

${ }^{36}$ See Rossella Brevetti, Administration, Democrats Reach Deal on Labor Standards in Free Trade Pacts, Daily Lab. Rep. (BNA) at A-15 (May 11, 2007).

${ }^{37}$ The U.S. business community opposed having the FTAs directly reference ILO conventions. Rossella Brevetti \& Jane Winebrenner, NAM Rejects Plan for ILO Standards for United States in Free Trade Pacts, Daily Rep. for Executives (BNA) at A7 (Apr. 20, 2007). ("NAM" is the National Association of Manufacturers.) In early 2007, the U.S. Council for International Business stated: "Since incorporating these [ILO] conventions into U.S. trade agreements would have the same effect as ratification, extensive revisions to U.S. state and federal labor laws would be necessary. The result would be radical changes to U.S. law in a manner that precluded debate or amendment in Congress or in state legislatures.” United States Council for International Business, U.S. Ratification of ILO Core Labor Standards at 2 (n.d.).

${ }^{38}$ Editorial, Deal or No Deal, WALL St. J., May 16, 2007, at A20. The editorial summarizes the new deal and explains: "This means the AFL-CIO will not be able to 
plan was agreed to in Washington, U.S. trade negotiators made an offer to each foreign counterpart that could not be easily refused: accept a set of treaty changes demanded by the United States on labor, environment, and other issues, or take a chance that the pending FTA would never be approved by Congress. Not surprisingly, all four countries accepted the offer and agreed to revisions in their FTA text.

As seen in the U.S.-Peru FTA, the new template on "fundamental labor rights" commits each party to "adopt and maintain in its statutes and regulations" the "rights" stated in the ILO declaration. ${ }^{39}$ In addition, the FTA mandates that "[n]either Party shall waive or otherwise derogate from ... its statutes or regulations" implementing those rights where the waiver or derogation would be inconsistent with a "fundamental right." To be a violation of these provisions, the challenged measure has to be "affecting trade or investment between the Parties. ${ }^{41}$ Failure to implement these provisions is subject to state-to-state dispute settlement by an independent panel. An uncorrected violation can lead to a monetary fine or, if unpaid, to a trade sanction. ${ }^{42}$

rewrite U.S. labor law by the back door and it should entail no new obligations for U.S. business."

${ }^{39}$ See, e.g., United States-Peru Trade Promotion Agreement, Art. 17.2(1), Apr. 12, 2006, with Protocol of Amendment, June 25, 2007, available at <http://www.ustr.gov>. For the United States, the term "statutes and regulations" is restricted to those at the central level of government. Id., Art. 17.8. The same template is included in the FTAs with Colombia, Panama, and South Korea.

${ }^{40}$ Id., Art. 17.2(2).

${ }^{41}$ Id., Art. 17.2 \& n.1.

${ }^{42}$ Id., Art. 21.16; see Office of the U.S. Trade Representative, Peru TPA Facts, Real Results on Labor Rights at 1 (July 2007), available at $<$ http://www.ustr.gov/Trade_Agreements/Bilateral/Peru_TPA/Section_Index.html> ("Available remedies are fines and trade sanctions, based on amount of trade injury."). 
The Peru-U.S. FTA contains a footnote stating that the obligations on fundamental labor rights "as they relate to the ILO, refer only to the ILO Declaration." This footnote was apparently added to clarify that the parties did not intend to incorporate by reference the rules of the fundamental ILO conventions, such as C. 87. Nevertheless, in seeking congressional votes for this FTA, leaders of the House Ways and Means Committee have been quick to describe it as a commitment to "adopt and enforce the five basic international labor standards." ${ }^{44}$ The term "international labor standards" is typically used to refer to ILO conventions and recommendations. ${ }^{45}$ Moreover, literature issued by the committee also asserted that the FTA would fully enforce "[b]asic labor standards as defined by the ILO.”46

These new disciplines on labor depart from all previous trade agreements. For the first time, parties have agreed to adhere to a minimum level of fundamental worker "rights" within their territories. Opinions differ on whether a trade agreement is an appropriate instrument for mutual obligations of this type ${ }^{47}$ In my view, while a trade

${ }^{43}$ United States-Peru Trade Promotion Agreement, supra note 39, Art. 17.2(1) \& n.2.

${ }^{44}$ Letter from Charles B. Rangel, chairman, House Committee on Ways and Means, and Sander M. Levin, chairman, Subcommittee on Trade, Committee on Ways and Means, to Democratic Colleagues (Sept. 18, 2007) (on file with author).

${ }^{45}$ See Nicolas Valticos, International Labour Standards and Human Rights: Approaching the Year 2000, 137 INT’L LAB. REV. 135, 135 \& n.2 (1998).

${ }^{46}$ House Comm. on Ways and Means, Peru FTA Contains Unprecedented Tools to Enforce Strong New Labor and Environmental Standards (n.d.), available at $<$ http://waysandmeans.house.gov/search.asp> (search "Peru FTA enforcement labor standards"; then follow

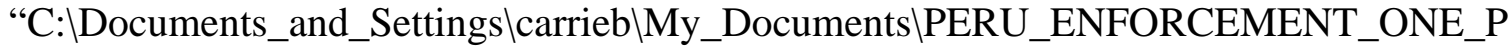
AGER.wpd” hyperlink).

${ }^{47}$ See Hard Labour for Trade Negotiators: Trade Deals Are Not the Place to Write Employment Law, FIN. TIMES (London), May 18, 2007, at 14; Chicago Council on Global 
agreement may be an appropriate instrument, it is surely not the optimal instrument. The ostensible advantage of using a trade agreement to make labor commitments lies in the availability of enforcement through trade sanctions. ${ }^{48}$ By contrast, labor treaties do not enable the use of trade sanctions for enforcement.

By the end of 2007, only one of the four pending FTAs with labor rights obligations had been approved by the U.S. Congress, the U.S.-Peru Agreement. ${ }^{49}$ The Peruvian Congress had already approved the revised FTA. ${ }^{50}$

Approval of the FTA with Peru by the U.S. Congress strengthens the international law commitment of the United States on worker rights. As seen above, in the ILO declaration of 1998, governments acknowledged that ILO membership itself conveys an obligation "to promote and to realize, in good faith ... the principles concerning the fundamental rights” that are the subject of fundamental ILO conventions, including "freedom of association and the effective recognition of the right to collective

Affairs, Poll Finds International Publics Strongly Favor Labor and Environmental Standards in Trade Agreements (Mar. 2007), available at $<$ http://www.thechicagocouncil.org/media_press_room_detail.php?press_release_id=59> (noting strong support in developing and developed countries for minimum labor standards in trade agreements).

${ }^{48}$ Kimberly Ann Elliott, The ILO and Enforcement of Core Labor Standards, INT'L ECON. POL'Y BRIEFS, July 2000, at 6-7, available at $<$ http://www.iie.com/publications/pb/pb00-6.pdf $>$. ${ }^{49}$ Rossella Brevetti, House Approves Peru FTA Measure; Majority of Democrats Vote Against Bill, Daily Rep. for Executives (BNA), at A-12 (Nov. 9, 2007); Steven R. Weisman, Senate Votes to Approve Trade Deal with Peru, N.Y. TIMES, Dec. 5, 2007, at C3; George W. Bush, Remarks with President Alan Garcia Perez of Peru on Signing the United States-Peru Trade Promotion Agreement Implementation Act, 43 WeEKLY ComP. PrEs. Doc. 1588 (Dec. 17, 2007); United States-Peru Trade Promotion Agreement Implementation Act, Pub. L. No. 110-138, 121 Stat. 1455 (2007) (to be codified at 19 U.S.C. $\$ 3805$ note). The U.S.-Peru FTA is not yet in force.

${ }^{50}$ Lucien O. Chauvin, Peru Congress OKs Amendments to Free Trade Pact with United States, Daily Rep. for Executives (BNA) at A-3 (June 29, 2007). 
bargaining. ${ }^{51}$ Yet in ratifying the U.S.-Peru FTA, the United States goes beyond the declaration, which was carefully drafted to key off the word "principles." Under the FTA, the United States gains a legal obligation to "adopt and maintain" the prescribed "rights," and not to waive or otherwise derogate from them. ${ }^{52}$

The implications of this new obligation were noted by Senator Hatch during the Senate debate on the U.S.-Peru FTA in December 2007. According to Senator Hatch:

Several provisions of the labor chapter of the U.S.-Peru trade agreement create an unacceptable risk that the United States will be required to change important provisions of U.S. Federal and state labor law or be subject to trade sanctions....

The Peru FTA does not provide any definition of these fundamental rights, leaving the interpretation of what constitutes "freedom of association" or “collective bargaining” to a dispute settlement panel appointed by the U.S. and Peruvian Governments.

Given the agreement's reference to the ILO declaration, it is widely expected that such a dispute settlement panel would in fact look at and rely at least partially on the standards of the relevant ILO core conventions associated

${ }^{51}$ See text at note 22 supra.

${ }^{52}$ See text at notes 39-40 supra. The FTA labor provision is a classic incomplete contract. The intentional vagueness of this new labor commitment would put an FTA dispute panel in a quandary of not knowing how to delineate the substantive content of the freedom of association "right" and whether to rely upon the relevant ILO case law. 
with these rights, much as the ILO does each year in its followup reports required by the ILO declaration. ${ }^{53}$

\section{U.S. PRACTICE ON ILO CONVENTIONS}

While making a legal commitment to Peru on labor rights certainly has repercussions beyond Peru, ${ }^{54}$ I find it odd, nonetheless, that a major new U.S. commitment on freedom of association is to be made only to Peru, rather than to all ILO members. ${ }^{55}$ As a supporter of freedom of association, I believe that the Peru FTA moves the United States in the right direction. Far better, however, would be for the United States to consider ratifying the multilateral treaty on freedom of association.

To be sure, the United States is already a party to the International Covenant on Civil and Political Rights, which states that "[e]veryone shall have the right to freedom of association with others, including the right to form and join trade unions for the protection of his interests. ${ }^{\text {} 56}$ Yet the international community recognizes C. 87 as the

53153 Cong. Rec. S14,722-23 (daily ed. Dec. 4, 2007).

${ }^{54}$ Although the commitment is bilateral to Peru, all of the U.S. labor obligations will be performed inside the United States. Whatever benefit this promised U.S. behavior confers outside the United States will not be enjoyed exclusively by Peru but, rather, will redound upon all countries.

${ }^{55}$ This is not to imply that enhancing legal protection for American workers was the object of the trade negotiation. Almost all of the domestic debate in 2007 about the new labor provision in the Peru-U.S. FTA concerned how to broaden Peru's obligations to the United States on fundamental labor rights. Little attention was given to the new labor obligations of the United States.

${ }^{56}$ International Covenant on Civil and Political Rights, Art. 22, Dec. 16, 1966, S. EXEC. Doc. No. 95-F (1978), 999 UNTS 171. The United States is also a party to the Racial Discrimination Convention, which commits parties to guarantee the right of everyone to 
most authoritative law on freedom of association. In comparison to the Covenant, the ILO instruments make a more robust complaint mechanism available to labor unions and employers. $^{57}$

The skittishness of the Senate toward the ILO may be an atavistic impulse going back to 1919 when the Senate considered, but failed to consent to, the Treaty of Versailles. One of the infamous treaty reservations adopted at that time stated that the United States was withholding its consent to the ILO-related part of the Treaty until Congress provided by law for U.S. participation. ${ }^{58}$ In 1934 both the Senate and the House acted to authorize U.S. participation in the ILO. ${ }^{59}$

Even as C. 87 was being negotiated in 1948, doubts were expressed in the United States as to whether the Convention would be approved by the Senate and, if so, whether changes in U.S. law would be needed. ${ }^{60}$ In the same year that the ILO adopted C. 87, a

equality before the law in the enjoyment of listed rights, including the "right to freedom of peaceful assembly and association." International Convention on the Elimination of All Forms of Racial Discrimination, Art. 5(d)(ix), Dec. 21, 1965, S. EXEC. Doc. No. 95C (1978), 660 UNTS 195.

57 Both the Covenant and the Racial Discrimination Convention, supra note 56, have optional protocols providing a process to receive communications from an individual alleging a violation of rights under the treaty. The United States, however, has not joined either optional protocol. In the ILO, no analogous optional protocols exist because labor unions may bring complaints under the regular supervisory mechanism.

${ }^{58}$ This reservation was approved by the Senate in both 1919 and 1920 . George A. Finch, The Treaty of Peace with Germany in the United States Senate, 14 AJIL 155, 181, 195 (1920).

59 S.J. Res. 43, 73d Cong., 48 Stat. 1182 (1934) (codified at 22 U.S.C. §271). Even before the United States joined the ILO, the Hoover administration had sent a tripartite delegation of observers to the annual ILO Conference. EDWARD C. LORENZ, DEFINING Global Justice: The History of U.S. InTERNATIONAL LABOR STANDARDS POLICy 97 (2001).

${ }^{60}$ Lawrence E. Davies, Broad Guarantees in ILO Agreement, N.Y. TimES, July 3, 1948, at 4. 
UN conference drafted a multilateral trade treaty known as the Charter of the International Trade Organization (ITO). Isolationist groups criticized both treaties. In April 1949, for example, the Daughters of the American Revolution (DAR) passed resolutions against them both. ${ }^{61}$ The U.S. business community was especially worried about the potential influence of ILO conventions on U.S. labor and employment law, and, in the early 1950s during the Bricker Amendment controversy, ILO conventions became one target of the debate. ${ }^{62}$ In her newspaper column in February 1953, Eleanor Roosevelt stated of Senator John Bricker:

The Senator attacks most violently the U.N. specialized agency called the International Labor Organization, saying it aims "to become economic overseer of all humanity.” This is amusing in view of the fact that in this organization[,] labor, employers and government are all represented, and they go over their agreements with great care. But any conclusion the ILO draws can only be put into effect in a nation that ratifies them, and we have ratified remarkably few of these conventions. ${ }^{63}$

${ }^{61}$ Bess Furman, 2 Agencies of U.N. Assailed by D.A.R.; U.S. Participation in ITO and ILO 'Freedom to Organize' Convention Opposed, N.Y. TIMES, Apr. 22, 1949, at 27. The United States decided not to participate in the ITO, and that organization never came into being.

${ }^{62}$ See, e.g., Oral History Interview with Philip Kaiser (June 8 \& 11, 1987), available at $<$ http://www.trumanlibrary.org/oralhist/kaiserp.htm>. In Senate hearings on the Bricker Amendment, three business representatives spoke against ratification of ILO conventions and particularly against C. 87. See U.S. Dep’t of Labor, supra note 9, at 54. U.S. employers perceived the ILO's approval of C. 87 in 1948 as an attempt to do an end run around the Taft-Hartley Labor Management Relations Act passed over President Truman's veto in 1947. JoHN BRUCE TIPTON, PARTICIPATION OF THE UNITED STATES IN THE INTERNATIONAL LABOR ORGANIZATION 86 (1959).

${ }^{63}$ Eleanor Roosevelt, My Day, Feb. 21, 1953, available at $<$ http://www.gwu.edu/ erpapers/myday/displaydoc.cfm?_y=1953\&_f=md002464>. 
A half century later, the United States has ratified just 14 of the 188 ILO Conventions.

Over the years, the United States relationship with the ILO has had its ups and downs. The first annual ILO Conference of 1919 was held in Washington, D.C., but the U.S. government did not send an official delegation. ${ }^{64}$ The legislation that authorized the ILO membership of the United States in 1934 had been promoted by Secretary of Labor Frances Perkins and by academics and nongovernmental organizations (NGOs) that envisioned ILO treaties as a potential constitutional justification for federal employment law in the era before the Supreme Court upheld federal fair labor standards. ${ }^{65}$ The United States began ratifying ILO conventions in 1938 when the Senate consented to five maritime conventions. ${ }^{66}$ Thereafter, the U.S. ratification rate slowed—with only one

${ }^{64}$ Nevertheless, there was considerable participation by Americans. For example, Secretary of Labor William B. Wilson was the 1919 conference chairman and Manley O. Hudson served as the legal adviser. Ursula P. Hubbard, The Cooperation of the United States with the League of Nations and with the International Labour Organization, INT'L Conciliation, No. 274, Nov. 1931, at 136.

${ }^{65}$ See Edward C. Lorenz, The Search for Constitutional Protection of Labor Standards, 1924-1941: From Interstate Compacts to International Treaties, 23 SEATTLE U. L. REV. 569, 587-594 (2000). The idea of using labor treaties in this manner appears to have originated with Joseph P. Chamberlain of Columbia University. See Joseph P. Chamberlain, Migratory Bird Treaty Decision and Its Relation to Labor Treaties, 10 AM. LaB. Legis. Rev. 133 (1920). The Supreme Court decision United States v. Darby, 312 U.S. 100 (1941), upheld the Fair Labor Standards Act and overruled the prior case law in Hammer v. Dagenhart, 247 U.S. 251 (1918).

${ }^{66}$ President Franklin D. Roosevelt began submitting ILO conventions to the Senate in 1936. The Officers' Competency Certificates Convention, 1936 (No. 53), the Holidays with Pay (Sea) Convention, 1936 (No. 54), the Shipowners' Liability (Sick and Injured Seamen) Convention, 1936 (No. 55), the Hours of Work and Manning (Sea) Convention, 1936 (No. 57), and the Minimum Age (Sea) Convention (Revised), 1936 (No. 58) were all ratified by the United States in 1938. ILO, Ratifications (Jan. 8, 2008), available at $<$ http://www.ilo.org/ilolex/english/newratframeE.htm>.When Senator Elbert D. Thomas proposed the adoption of the five ILO conventions in 1938, he told the Senate that "American standards are so much higher than any of these conventions recommend," and 
ratification in the 1940s, one in the 1950s, and none in the 1960s, 1970s, or early 1980s. ${ }^{67}$ In the early 1970s, all of the U.S. participants in the ILO — the workers, employers, and the federal government—became increasingly dissatisfied with political developments in the organization. ${ }^{68}$ This situation led to U.S. withdrawal in 1977. After some practices of the ILO were improved, the United States rejoined in $1980 .{ }^{69}$

Owing to the efforts of Senator Daniel Patrick Moynihan, the Senate began to break the logjam in ILO conventions in 1988 when it consented to the Tripartite Consultation Convention, 1976 (No. 144) and the Merchant Shipping (Minimum Standards) Convention, 1976 (No. 147). During the 1990s, the Senate consented to four ILO conventions - the Labour Statistics Convention, 1985 (No. 160), approved in 1990; the Abolition of Forced Labour Convention, 1957 (No. 105), approved in 1991; the Labour Administration Convention, 1978 (No. 150), approved in 1994; and the Worst Forms of Child Labour Convention, 1999 (No. 182), approved in 1999. In 2000 the Safety and Health in Mines Convention, 1995 (No. 176) received consent. ${ }^{70}$ Since the

that with the conventions universally adopted, "our own ships may compete on a better level with the ships of other countries which have lower standards." 83 CONG. REC. 9023-24 (1938). Two additional ILO conventions sent to the Senate in 1938 were not ratified.

${ }^{67}$ The Final Articles Revision Convention, 1946 (No. 80) was ratified by the United States in 1948. The Certification of Able Seamen Convention, 1946 (No. 74) was ratified by the United States in 1953. ILO, supra note 66.

${ }^{68}$ See, e.g., Stephen M. Schwebel, The United States Assaults the I.L.O., 65 AJIL 136 (1971).

${ }^{69}$ Stephen I. Schlossberg, United States' Participation in the ILO: Redefining the Role, 11 COMP. LAB. L. 48, 70-72 (1989) (discussing the grounds for U.S. withdrawal and reentry).

${ }^{70}$ ILO, supra note 66. 
retirement of Senator Moynihan in 2000, the Senate has not considered any more ILO conventions.

Senator Moynihan moved ahead on all seven of the ILO conventions that he shepherded through the Senate only after each one received the tripartite support of the executive branch, labor, and employers. The forum used to weave together that support was the President's Committee on the International Labor Organization, which was established by executive order in 1980 and reauthorized regularly since then. ${ }^{71}$ The committee is chaired by the secretary of labor and includes as members the secretary of state, the secretary of commerce, the assistant to the president for national security affairs, the assistant to the president for economic policy, and one representative each from organized labor and the business community. ${ }^{72}$ In practice, organized labor has been represented by the AFL-CIO, and the business community by the U.S. Council for International Business. To aid it in its work, the committee has established the Tripartite

${ }^{71}$ Exec. Order No. 12,216, 45 Fed. Reg. 41,619 (June 20, 1980), reprinted in 22 U.S.C. $\S 271$ note (2000) [hereinafter President's Committee on the ILO].

${ }^{72}$ The absence of and need for "an advisory policy committee composed of government, employer and worker representatives" had been pointed out by the Johnson Committee in 1956. Johnson Committee Report, supra note 25, at 184. The Johnson Committee was appointed by the U.S. Departments of State, Commerce, and Labor to conduct an independent review of U.S. policies toward the ILO. (The committee was headed by Joseph E. Johnson, the president of the Carnegie Endowment for International Peace.) The committee's recommendations for better coordinating machinery were not acted upon until 1980, and this long delay undermined U.S. policy coherence. More than two decades before the Johnson Committee Report, Manley O. Hudson had advised that U.S. opportunities in the ILO "will be grasped, however, only if the various departments of the government are organized to that end and if the Government of the United States shows itself, from the beginning, determined to make its membership more than a matter of routine.” Manley O. Hudson, The Membership of the United States in the International Labor Organization, 28 AJIL 669, 682 (1934). 
Advisory Panel on International Labor Standards, composed of legal advisers from the member entities.

Gaining Senate approval of additional fundamental ILO conventions will be difficult. ${ }^{73}$ Those conventions trigger the same concerns about treaty supremacy that have sometimes ensnared human rights treaties in the United States. ${ }^{74}$ As with treaties generally, ILO conventions have the potential to be directly applied by U.S. courts. In the 1951 case Warren v. United States, the Supreme Court held that the United States, as owner of a merchant ship, was liable to a seaman for injuries he had suffered on shore leave. ${ }^{75}$ In deciding the case, the Court appeared to accept the applicable ILO convention as U.S. law that could create rights for individuals. The reluctance to consider ratifying additional fundamental ILO conventions can also be attributed to the existence of detailed, contentious federal labor law regulating the same issues covered by the ILO conventions.

${ }^{73}$ Besides C. 87, the other fundamental ILO convention now before the U.S. Senate is the Discrimination Convention (No. 111). It was transmitted to the Senate by President William J. Clinton in May 1998. Nearly ten years later, the Senate Foreign Relations Committee has yet to hold a public hearing on C. 111 .

${ }^{74}$ As Professor Henkin noted in 1995, U.S. ratification of human rights conventions has sometimes been predicated on the principle that "adherence to a convention will not change, or require change, in U.S. laws, policies or practices, even where they fall below international standards." Louis Henkin, U.S. Ratification of Human Rights Conventions: The Ghost of Senator Bricker, 89 AJIL 341, 342 (1995). Henkin criticizes Senateimposed reservations designed to reject any obligation above existing U.S. law and practice.

${ }^{75}$ Warren v. United States, 340 U.S. 523 (1951). The central issue in the case was the meaning of the Shipowners' Liability Convention (No. 55) in U.S. law. On Warren and the ILO, see VIRGINIA A. LEARY, INTERNATIONAL LABOUR CONVENTIONS AND NATIONAL LAW 77-82 (1982); Nicolas Valticos, The International Labour Organization, in THE EFFECTIVENESS OF INTERNATIONAL DECISIONS: PAPERS OF A CONFERENCE OF THE AMERICAN SOCIETY OF INTERNATIONAL LAW, AND THE PROCEEDINGS OF THE CONFERENCE 134, 141-42 (Stephen M. Schwebel ed., 1971). 
In past Senate approvals of ILO conventions, the resolutions of ratification have sometimes included a specially crafted understanding or declaration. For the Abolition of Forced Labour Convention (No. 105), the Senate adopted an understanding that the conclusions and practice of the ILO Committee of Experts on the Application of Conventions and Recommendations "are not legally binding on the United States and have no force and effect on courts in the United States. ${ }^{, 76}$ For the Worst Forms of Child Labour Convention (No. 182), the Senate adopted an understanding that Article 3(d) of the Convention ${ }^{77}$ does not encompass situations in which children are employed by a parent, and does not change U.S. agricultural employment law or the Fair Labor Standards Act. ${ }^{78}$ Neither of these Senate resolutions, for C. 105 or C. 182, included a declaration characterizing the Convention as non-self-executing. But in 2000, when the Senate approved the Safety and Health in Mines Convention (No. 176), the resolution contained a declaration that "[t]he United States understands that the Convention is not self-executing., ${ }^{, 79}$ The United States has not sought to attach a reservation to an ILO convention. In ILO practice, treaty reservations are not accepted. ${ }^{80}$

When it consented to the ILO Convention on Tripartite Consultation to Promote the Implementation of International Labour Standards (No. 144), the Senate's resolution of advice and consent to ratification memorialized ground rules for U.S. implementation

${ }^{76} 137$ Cong. REC. S10,790-91 (daily ed. May 14, 1991).

${ }^{77}$ Article 3(d) of ILO Convention No. 182, supra note 26, concerns work that, "by its nature or the circumstances in which it is carried out, is likely to harm the health, safety or morals of children.”

${ }^{78} 145$ CoNG. REC. S28,858 (daily ed. Nov. 5, 1999).

79146 Cong. Rec. S18,766 (daily ed. Sept. 20, 2000). 
of the Convention, ${ }^{81}$ including decisions to submit ILO conventions to the U.S. Senate. Those ground rules had been adopted in 1985 by the President's Committee on the ILO. The Senate resolution on C. 144 states:

There is agreement by the U.S. Government agencies concerned, the AFLCIO, and the U.S. Council for International Business, that each ILO convention will be examined on its merits on a tripartite basis; that if there are any differences between the convention and Federal law and practice, these will be dealt with in the normal legislative process; and that there is no intention to change State law and practice by Federal action through ratification of ILO conventions, and the examination will include possible conflicts between Federal and State law that would be caused by such ratification. ${ }^{82}$

In discussing this resolution, which he had helped craft, Senator Moynihan explained:

Under the ground rules, only conventions that are in conformance with U.S. law and practice, or conventions for which implementing legislation has been introduced to reconcile the difference between U.S. law and practice and a convention's requirements, are appropriate for Senate action. In other words,

\footnotetext{
${ }^{80}$ Laurence R. Helfer, Understanding Change in International Organizations: Globalization and Innovation in the ILO, 59 VAND. L. REV. 649, 686 (2006). ${ }^{81}$ Articles 2 and 5(1)(b), (c) of the Convention Concerning Tripartite Consultation to Promote the Implementation of International Labour Standards (No. 144) require a government to conduct domestic consultations with employer and worker organizations regarding the ratification of ILO conventions. In my view, these provisions do not apply to C. 87 because it has already been submitted to the U.S. Senate.

82134 Cong. Rec. S473, 474 (daily ed. Feb. 1, 1988).
} 
consideration of other conventions that do not fit in these two categories would violate the ground rules and would be presumptively inappropriate for Senate action. $^{83}$

The central principle of the ground rules seems to be that ILO conventions, as treaties under the U.S. Constitution, will not be used as a back door for changing federal and state labor law.

One can observe various actors putting their own spin on the ground rules. According to the U.S. Department of Labor, those rules state that "no ILO convention will be ratified unless or until U.S. law and practice, at both the federal and state levels, is in full conformity with its provisions." ${ }^{84}$ According to the U.S. Council for International Business, the rules dictate that "no ILO convention will be forwarded to the U.S. Senate for ratification if ratification would require any change in U.S. federal or state laws.”85

In my view, the ground rules do not assert that when U.S. law is inconsistent with an ILO convention, ratification of that convention is off the table. Rather, they suggest that when such an inconsistency exists, Congress must change U.S. law (or begin doing so) before the convention will be acted upon by the Senate. In assessing whether U.S. labor standards should be brought up to the international level, each ILO convention is to "be examined on its merits."

${ }^{83}$ Id. at $\mathrm{S} 479$.

${ }^{84}$ U.S. Dep’t of Labor, Bureau of International Labor Affairs, International Labor Organization (ILO), available at <http://www.dol.gov/ilab/programs/oir/ILO.htm>. ${ }^{85}$ U.S. Council for International Business, Issue Analysis: U.S. Ratification of ILO Core Labor Standards 4 (Apr. 2007), available at $<$ http://www.uscib.org/index.asp?documentID=1926>. 


\section{COMPATIBILITY OF C. 87 WITH EXISTING U.S. LAW}

The Tripartite Advisory Panel has not examined whether U.S. law and practice meets the standards in the ILO Convention on Freedom of Association. Indeed, to my knowledge, there has never been a tripartite or independent study comparing C. 87 to U.S. law. In view of the complexity of U.S. labor law and administrative practice, the variation among states, and the continuing elaboration of C. 87 by CFA decisions, such an exercise would be a major effort. Nevertheless, a comprehensive analysis ought to be undertaken to see what changes in U.S. federal and state law would be needed to comply with C. 87.

Two studies in the public domain address the consistency of U.S. law with C. 87. In 1980 the Office of the Solicitor of the U.S. Department of Labor concluded that "Convention No. 87 may be unequivocally ratified by the United States without entailing any undertaking to enact legislation or to modify existing law." ${ }^{\text {} 86}$ That study took note of concerns that "creative judicial construction" of the Convention might nullify domestic legislation, and therefore suggested a possible remedy of crafting a special declaration or

\footnotetext{
${ }^{86}$ U.S. Dep't of Labor, supra note 9, at 49. The briefing paper was based on a 1976 study that was not published. The briefing paper and the study focused on the potential inconsistencies between the Convention, on the one hand, and the Labor-Management Reporting and Disclosure Act of 1949, 29 U.S.C. \$89 (Landrum-Griffin Act), and the Labor Management Relations Act of 1947, 29 U.S.C. \$141 (Taft-Hartley Act), on the other. Back in 1971, a U.S. interagency report (overseen by the U.S. Department of Labor) had urged ratification of C. 87. WALTER GALENSON, THE INTERNATIONAL LABOR ORGANIZATION: AN AMERICAN VIEW 116-17, \& 318 n.14 (1981).
} 
understanding to avoid that result. ${ }^{87}$ In 1984 Edward Potter, a legal counselor to the U.S. employer delegation to the ILO, wrote a lengthy study published by the Labor Policy Association. ${ }^{88}$ Potter concluded that if C. 87 were ratified and, as a treaty, superseded contrary requirements in U.S. legislation, the Convention would affect or alter U.S. labor law in many significant ways. ${ }^{89}$ Another section of his study considered the possibility of ratifying C. 87 and C. 98 on a non-self-executing basis, but concluded that without U.S. implementing legislation, the U.S. obligations under those two conventions would be breached.

Periodically, the U.S. government is asked by the ILO to report on the status of C. 87 in the United States. ${ }^{90}$ The most recent report came in 1994 when the government stated "that although no recent in-depth tripartite analysis has been performed regarding

${ }^{87}$ U.S. Dep't of Labor, supra note 9, at 49. The suggested declaration was to state that C. 87 is non-self-executing.

${ }^{88}$ EdWARD E. PotTer, FreEdom OF Association, THE Right to Organize AND COLLECTIVE BARGAINING: THE IMPACT ON U.S. LAW AND PRACTICE OF RATIFICATION OF ILO CONVENTIONS No. 87 AND No. 98 (1984).

${ }^{89}$ For example, Potter found that ratification would "[a]lter a fundamental principle of U.S. labor law, which makes union rights derivative from those of employees, by subordinating employee rights to those of labor organizations.” Id. at 44. In a recent article, Potter remarked that his 1984 study remains valid and then stated:

Unqualified ratification of one or both of those conventions [Nos. 87 and 98] would redirect US labour policy significantly. To mention just two [examples]: the conventions would broaden the right to strike but give representation rights to minority unions; and they would revoke or modify substantial portions of the Landrum-Griffin Act, but would remove limits on disaffiliations of local unions from international unions.

Edward Potter, The Growing Importance of the International Labour Organization: The View from the United States, in GlOBALIZATION AND THE FUTURE OF LABOUR LAW 356, 371 (John D. R. Craig \& S. Michael Lynk eds., 2006).

${ }^{90}$ The requirement for reporting in the general survey is found in the Constitution of the ILO, supra note 1, Art. 19(5)(e). 
this Convention, federal legislation appears to be in general conformity with the Convention: no additional measure is envisaged, including as regards ratification of the Convention." ${ }^{91}$ The first annual report (2000) by the U.S. government under the 1998 ILO declaration was more nuanced and revealing. That report notes the elaborate system of substantive labor law, and then states: "Nonetheless, the United States acknowledges that there are aspects of this system that fail to fully protect the rights to organize and bargain collectively of all employees in all circumstances."92

As noted above, even though it is not a party to C. 87 and C. 98, the United States is subject to complaints brought against it in the CFA. In the most recent decision involving the United States, the CFA ruled in 2007 that certain provisions in North Carolina law ban trade unions in the public sector from engaging in collective bargaining, and that these provisions are contrary to both C. 87 and C. $98 .{ }^{93}$

Other analysts agree that U.S. labor law and practice can be inconsistent with C. 87. For example, Janice R. Bellace has written that the United States could not easily ratify C. 87 because "American law permits major gaps in protection [of workers] to

${ }^{91}$ ILO, General Survey, 1994, Freedom of Association and Collective Bargaining: Ratification of Conventions: Difficulties and Prospects, Convention No. 87, para. 292, available at $<$ http://www.ilo.org/ilolex/english/surveyq.htm>.

${ }^{92}$ Compilation of Annual Reports by the International Labour Office, 2000, Freedom of Association and the Effective Recognition of the Right to Collective Bargaining: United States, available at $<$ http://www.ilo.org/dyn/declaris/DECLARATIONWEB.ANNUALREVIEWDATABAS E?var_language=EN>.

${ }^{93}$ Complaint Against the Government of the United States Presented by the United Electrical, Radio and Machine Workers of America (UE), supported by Public Services International (PSI), Report No. 344, Case No. 2460, para. 991, available at $<$ http://www.ilo.org/ilolex/english/caseframeE.htm>. Close observers of CFA jurisprudence perceive a harsher tone in this decision, as compared to previous U.S. cases, in applying C. 87 requirements to the United States. 
exist." ${ }^{94}$ James A. Gross has written that the U.S. government "is not ensuring within its territory the exercise of the right of freedom of association at the workplace." ${ }^{\text {,95 }}$ My own opinion is that the Truman administration's statement to the U.S. Senate in 1949 quoted above, ${ }^{96}$ suggesting that ratification of C. 87 would not require any changes in U.S. law, would not be correct today.

Although I have heard it said that U.S. ratification of C. 87 could actually undermine employee rights in the United States, I have never seen that argument expounded in an intelligible way. Any interpretation of C. 87 should be guided by the provision of the ILO Constitution that states:

In no case shall the adoption of any Convention or Recommendation by the Conference, or the ratification of any Convention by any Member, be deemed to affect any law, award, custom or agreement which ensures more favourable conditions to the workers concerned than those provided for in the Convention or Recommendation. ${ }^{97}$

\footnotetext{
${ }^{94}$ Janice R. Bellace, The Future of Employee Representation in America: Establishing Freedom of Association in the Workplace in Changing Times Through Statutory Reform, 5 U. PA. J. LAB. \& EMP. L. 1, 30 (2002).

95 James A. Gross, A Human Rights Perspective on United States Labor Relations Law: A Violation of the Right of Freedom of Association, 3 EMPLOYEe RTS. \& EMP. POL’y J. 65, 103 (1999).

${ }^{96}$ See text at note 8 supra.

${ }^{97}$ ILO Const., supra note 1, Art. 19(8). This provision was proposed by the United States in 1919. David Hunter Miller, Some Results of the Labor Clauses of the Treaty of Versailles, 6 CORNELL L.Q. 133, 153 (1921).
} 
The most salient feature of the U.S. domestic "debate” about ratification of C. 87 is that no ongoing debate occurs. The notion that the United States would actually ratify this basic human rights convention is so unimaginable that it is hardly ever discussed. As noted above, the president's committee and the Tripartite Advisory Panel have never put C. 87 on their agenda. Furthermore, U.S. human rights groups and labor unions have not campaigned for U.S. ratification. ${ }^{98}$ The U.S. business community would be strongly opposed, and appears to take the position that ratification of an ILO convention would be inappropriate unless that instrument conforms to U.S. law.

U.S. acceptance of international agreements in many other fields of law differs, in that elected officials, NGOs, and the business community seek the adoption of federal implementing legislation concomitantly with Senate approval of the new instrument. The most innovative process is applied to trade agreements, whose approval is voted by the full Congress, not just the Senate, and is given in the same legislative vehicle that enacts the implementing legislation. For example, approval of the North American Free Trade Agreement (NAFTA) was accomplished through legislation that amended U.S. sanitary

\footnotetext{
${ }^{98}$ The only recent pro-ratification statement that I am aware of occurred in 2000, when Human Rights Watch issued a report on freedom of association suggesting that the United States ratify C. 87 and C. 98. Human Rights Watch, Unfair AdVANTAGE: WORKERS' FREEDOM OF ASSOCIATION IN THE UNITED STATES UNDER INTERNATIONAL HUMAN RIGHTS STANDARDS 24 (2002), available at <http://hrw.org/reports/pdfs/u/us/uslbr008.pdf>. In 1995 the American Bar Association House of Delegates approved a more cautious recommendation urging "accelerated progress" toward "ratification of those ILO conventions on human rights which are consistent with U.S. law and practice." A.B.A., Section of International Law and Practice, Report to the House of Delegates, International Labor Organization, 30 INT'L LAW. 653, 653-54 (1996) (emphasis added).
} 
and phytosanitary laws so as to conform them to the NAFTA. Likewise, the Agreement Establishing the World Trade Organization (WTO) was effectuated by legislation that conformed U.S. intellectual property law to the WTO’s Agreement on Trade-Related Aspects of Intellectual Property Rights. Moreover, all trade agreements approved by Congress must receive implementing legislation to alter tariffs and customs treatment. Such legislation includes a provision stating that in the event of a conflict between the trade agreement and U.S. law, the latter will prevail. ${ }^{99}$

The availability of bicameral fast-track procedures to approve new trade agreements ${ }^{100}$ has enabled the strengthening of international trade law and U.S. participation in it. Because Congress has not provided for such procedures for U.S. treaty making in other fields, the United States can more easily make new international labor commitments through a trade agreement than through an ILO convention (or a bilateral labor treaty). Similarly, the labor law commitments the United States seeks from other countries are legalized more easily through a trade agreement than through a labor agreement.

Whether the United States should ratify C. 87 and, if necessary, raise U.S. law to international standards should be decided with reference to U.S. objectives in both foreign and domestic policy. When he testified to Congress about ILO conventions in 1985, Secretary of State Shultz put forward the proposition, "looking at it from the standpoint of our foreign policy objectives and our effectiveness for work within the ILO

99 See, e.g., 19 U.S.C. §3512(a) (2000).

100 U.S. fast-track authority for new trade agreements expired on July 1, 2007. 
organization, that we ought to be willing to look at these conventions on their merits.”101 Unfortunately, the U.S. Senate has failed to examine C. 87 on its merits. Indeed, since 1949 the Committee on Foreign Relations has never found time to hold a public hearing on the Freedom of Association Convention.

How should the United States move forward? As of the end of 2007, President George W. Bush had not called a meeting of the President's Committee on the ILO during his incumbency. The next president should convene this committee and ask it to undertake an objective examination of any inconsistencies between U.S. law and C. 87. In doing so, the president should expand the committee's membership to include a representative of state governments.

The committee should also consider whether refinements are needed in the 1985 ground rules to take into account the impracticality of assuring, before ratification is undertaken, that no U.S. law or practice violates the ILO convention under review. The current approach is especially unsuitable when complaint mechanisms apply to the convention, as with C. 87, resulting in the constant evolution of the case law. To generalize the point: in complex, rule-based multilateral regimes, breaches of a treaty are to be expected even by nations that observe almost all of their obligations almost all of the time. ${ }^{102}$

${ }^{101}$ The United States and the International Labor Organization, supra note 9, at 5, 14.

${ }^{102}$ Note that the International Labour Office recognizes that some countries "ratify ILO conventions fairly quickly and then work to bring their national law and practice into line; the comments of the ILO's supervisory bodies and technical assistance . . . can guide them in this process.” ILO, RULES OF THE GAME: A BRIEF INTRODUCTION TO INTERNATIONAL LABOUR STANDARDS 18 (2005), available at $<$ http://www.ilo.org/public/english/standards/norm/index.htm>. 
The president's committee might usefully reflect on the example of U.S.

participation in the WTO, where the dispute settlement system regularly finds the United States noncompliant with the WTO treaty. ${ }^{103}$ Such adjudications then trigger efforts in Congress or federal agencies to bring the United States into compliance. This dialectical process has its tensions, but its wisdom can be seen by imagining the alternative scenario: the United States waits (forever) to join the WTO until it can be sure that no domestic law or practice violates WTO law. The lesson from the WTO experience is that achieving and sustaining national compliance must be a continuous process.

If a tripartite review of C. 87 identifies specific statutory provisions that fall below the international standard, Congress should examine whether legal reforms should be adopted. ${ }^{104}$ The U.S. labor market is not isolated from those of other countries, and can potentially gain if U.S. law is adapted to reflect more effective foreign practices in

${ }^{103}$ Since 1995, WTO panels have found U.S. violations in thirty-three separate cases. Other WTO members besides the United States are also regularly found to be out of compliance. Numerous WTO cases have been about measures adopted after the WTO went into force, yet many others have been about measures in place when the country joined the WTO. The WTO dispute system makes no distinction between those two temporal categories.

${ }^{104}$ If changes at the subnational level would be needed to achieve conformity, then Congress ought to consider requiring such changes. In other words, Congress should revisit the position in the current ground rules, see text at notes 81-82 supra, that U.S. ratification of an ILO convention should not change state labor law and practice. In that regard, one might recall a U.S. government position expressed to the ILO in 1975 that the "United States could not assume a treaty obligation for a Convention whose partial jurisdiction lies in the states. Such an action would alter the distribution of powers between the states and the federal Government." ILO Governing Body, Analysis of Replies to the Questionnaire on International Labour Standards, Doc.

GB.198/PFA/11/22, at 67 (Nov. 1975). 
achieving freedom of association. Congress ought not to start on the assumption that the American economy is locked into the U.S. labor laws enacted over sixty years ago. ${ }^{105}$

Ultimately, persuading the Senate to take up C. 87 will require leadership within that body. ${ }^{106}$ To get the gears moving, human rights NGOs and U.S. labor unions might consider establishing a "Sixty Years Is Enough" campaign to underline how the Senate has failed in its duty to consider C. 87. Although many sitting senators portray themselves as paladins of the American worker, none seems to show much interest in the Freedom of Association Convention. By way of counterexample, the heroic determination of Senator William Proxmire comes to mind. Proxmire was so dedicated to

${ }^{105}$ See Cynthia L. Estlund, An American Perspective on Fundamental Labour Rights, in SOCIAL AND LABOUR RightS IN A GLOBAL CONTEXT 192, 201 (Bob Hepple ed., 2002) (noting that "there has been no major labour law reform - that is, reform of collective labour rights and labour-management relations - since 1947, when the Taft-Hartley amendments added a rash of anti-labour provisions").

${ }^{106}$ Moreover, Senate consent to the Convention will require a two-thirds vote, which would seem difficult to obtain if the business community opposes that action. Reportedly, there is also concern among American sovereigntists because the ILO Constitution provides for possible referrals to the ICJ. See ILO Const., supra note 1, Arts. 29(2), 37(1); see also note 20 supra. No such referrals to the ICJ have occurred, however, and the possibility that a state could be brought to the ICJ against its will seems remote. If a state were the object of an Article 29 commission of inquiry and were found to be in violation of an ILO convention it had ratified, the state could decide against referring the matter to the ICJ. The other provision for ICJ referral is Article 37(1) of the ILO Constitution, which states that "[a]ny question or dispute relating to the interpretation of this Constitution or of any subsequent Convention concluded by the Members ... shall be referred for decision to the International Court of Justice.” Yet by its terms, Article 37(1) seems to be about questions of interpretation, rather than questions of implementation by a particular state. Moreover, Article 37(1) is not preconditioned on whether a member state has ratified a particular ILO convention. Hence, ratification of C. 87 does not trigger a new possibility of an ICJ referral. 
U.S. ratification of the Genocide Convention that he delivered a speech on the Senate floor every day from 1967 until the resolution of ratification was adopted in $1986 .{ }^{107}$

A question for 2008 and beyond is whether there are any U.S. senators who care enough about the ILO and worker rights to champion U.S. ratification of the Convention on Freedom of Association.

107 LaWrence J. LeBlanc, The United States And the Genocide ConVention 6 (1991). And Proxmire began his campaign many years before the invention of C-SPAN! 